\title{
Staying Well and Engaged When Demands Are High: The Role of Psychological Detachment
}

\author{
Sabine Sonnentag \\ University of Konstanz
}

\author{
Carmen Binnewies \\ University of Mainz
}

Eva J. Mojza

University of Konstanz

\begin{abstract}
The authors of this study examined the relation between job demands and psychological detachment from work during off-job time (i.e., mentally switching off) with psychological well-being and work engagement. They hypothesized that high job demands and low levels of psychological detachment predict poor well-being and low work engagement. They proposed that psychological detachment buffers the negative impact of high job demands on well-being and work engagement. A longitudinal study (12-month time lag) with 309 human service employees showed that high job demands predicted emotional exhaustion, psychosomatic complaints, and low work engagement over time. Psychological detachment from work during off-job time predicted emotional exhaustion and buffered the relation between job demands and an increase in psychosomatic complaints and between job demands and a decrease in work engagement. The findings of this study suggest that psychological detachment from work during off-job time is an important factor that helps to protect employee well-being and work engagement.
\end{abstract}

Keywords: job demands, emotional exhaustion, work engagement, psychological detachment, recovery

In many contemporary jobs, employees face a high level of quantitative job demands reflected in a high workload and time pressure. High job demands not only produce a stressful short-term experience (Ilies et al., 2007) but also cause poor well-being over time (De Lange, Taris, Kompier, Houtman, \& Bongers, 2003) and often result in high health care costs (Ganster, Fox, \& Dwyer, 2001). Scholars addressing physiological (Linden, Earle, Gerin, \& Christenfeld, 1997; McEwen, 1998) and organizational (Geurts \& Sonnentag, 2006; Trougakos, Beal, Green, \& Weiss, 2008; Westman \& Eden, 1997) processes have argued that exposure not only to high demands and immediate responses to these demands but also to processes associated with recovery (i.e., unwinding and

Editor's Note. Sharon K. Parker served as action editor for this article.SWJK

This article was published Online First August 16, 2010.

Sabine Sonnentag and Eva J. Mojza, Department of Psychology, University of Konstanz, Konstanz, Germany; Carmen Binnewies, Department of Psychology, University of Mainz, Mainz, Germany.

This research was funded by Grant SO 295/4-1, 4-2 from the German Research Community (DFG) that is gratefully acknowledged. We thank Franziska Bertram, Claudius Bornemann, Sabrina Engel, Stefanie Ernst, Verena Hahn, Till Kastendieck, Nadja Metzler, Frithjof Müller, Alessa Münch, Christian Lorenz, Sonja Riefer, Annika Scholl, Julia Schweda, Pascal Sailer, Ines Spitzner, and Raphael von Varendorff for their support during data collection and Jessica de Bloom and Jana Kühnel for very helpful comments on an earlier version of this article.

Correspondence concerning this article should be addressed to Sabine Sonnentag, Department of Psychology, University of Konstanz, Box 42, Konstanz D-78457, Germany. E-mail: sabine.sonnentag@uni-konstanz.de recuperation processes that alleviate negative effects of demands and reduce short-term strain reactions; Craig \& Cooper, 1992) are crucial for understanding the human organism, employee wellbeing, and job performance.

Sonnentag and Bayer (2005) suggested that psychological detachment from work during off-job time facilitates recovery. Psychological detachment refers to an "individual's sense of being away from the work situation" (Etzion, Eden, \& Lapidot, 1998, p. 579). It implies that one is not working at home and not thinking about job-related issues, problems, or opportunities during afterwork hours. In everyday life, psychological detachment from work is experienced as "switching off" and means leaving the workplace temporarily behind oneself in physical and in mental terms.

So far, research on psychological detachment from work during nonwork time mainly has focused on direct relations between detachment and outcomes measures (Sonnentag \& Fritz, 2007; Taris, Geurts, Schaufeli, Blonk, \& Lagerveld, 2008). MorenoJiménez and his co-workers have argued that psychological detachment may also attenuate the relation between stressors and strains (Moreno-Jiménez, Mayo, et al., 2009; Moreno-Jiménez, Rodrígez-Munro, Pastor, Sanz-Vergel, \& Garrosa, 2009). Their empirical tests, however, have been limited to specific stressors such as workplace bullying and work-family conflict, and the question of whether detachment from work moderates the association between job demands and impaired well-being has not been examined. Finding moderators for this relation is particularly important because high job demands are very common in contemporary jobs and because organizations may also see performance benefits of high job demands (LePine, Podsakoff, \& LePine, 2005) and thereby might be unwilling to reduce high job demands. Thus, additional approaches to protect employee well-being are needed. 
Until now, researchers conducting empirical studies on psychological detachment from work during off-job time have used cross-sectional designs (Sonnentag \& Fritz, 2007; Taris et al., 2008) or examined short-term processes, often comparing lowdetachment versus high-detachment days within persons (Sonnentag \& Bayer, 2005; Sonnentag, Binnewies, \& Mojza, 2008). In such research, any possible longer term effects of between-person differences in psychological detachment are neglected. Longitudinal between-person studies are necessary in order for researchers to gain insight as to whether psychological detachment from work during nonwork time may protect well-being in the longer term and to test whether processes identified at the within-person level hold also at the between-person level (Affleck, Zautra, Tennen, \& Armeli, 1999).

We pursued three specific aims with this study. First, we tested interaction effects between job demands and psychological detachment to find out if detachment from one's job during off-job time can buffer the negative impact of high job demands on well-being. In addition to moderators tested in past research (e.g., job control, social support, self-efficacy; Jex \& Yankelevich, 2008), psychological detachment is a particularly promising and important moderator because it is largely under the discretion of employees themselves. Second, we used a longitudinal design in order to test if psychological detachment predicts psychological well-being over time. In our study, we examined psychological detachment as a person's general behavior of relating to his or her job during nonwork time and thereby went beyond earlier research in which short-term implications of psychological detachment were tested at the day level (e.g., Sonnentag, Binnewies, et al., 2008). Compared with previous cross-sectional research, our longitudinal design provides more possibilities to rule out alternative interpretations such as reverse causation. It is an important step toward establishing a causal link between psychological detachment and wellbeing. Third, we used a broad conceptualization of psychological well-being including two indicators of impaired well-being (emotional exhaustion and psychosomatic complaints) and work engagement-a positive well-being indicator (cf. Schaufeli, Taris, \& van Rhenen, 2008). Adding work engagement as outcome variable is important because predictors and outcomes of work engagement are not always identical to the predictors and outcomes of impaired well-being (Bakker \& Demerouti, 2007). Accordingly, our research can offer implications for practice. If psychological detachment is shown to be a predictor or moderator in our study, employees should be encouraged to develop strategies for detaching themselves from their work during off-job time (cf. Kreiner, Hollensbe, \& Sheep, 2009).

\section{Job Demands and Psychological Well-Being}

We built our study on research into the relation between job demands and psychological well-being and aimed at replicating and extending earlier findings by looking at emotional exhaustion, psychosomatic complaints, and work engagement. Emotional exhaustion as a core burnout dimension (Maslach, Schaufeli, \& Leiter, 2001) refers to the depletion of mental resources. Psychosomatic complaints include symptoms such as stomach or cardiac complaints, sleep problems, sweating, or bodily agitation (Warr, 2007). Impaired psychological well-being is related to poor job performance (Taris, Le Blanc, Schaufeli, \& Scheurs, 2005) and predicts more severe health problems and increased use of sick leave (Darr \& Johns, 2008).

In addition to indicators of impaired psychological well-being, we examined work engagement as a positive indicator of jobrelated well-being. Schaufeli and Bakker (2004, p. 295) defined work engagement as a "positive, fulfilling, work-related state of mind" that comprises vigor, dedication, and absorption. Vigor implies a high level of energy and mental resilience at work and a willingness to invest effort and to persist in the face of difficulties. Dedication refers to enthusiasm, inspiration, and the experience of significance and pride at work. Absorption implies full concentration and the experience of being engrossed in one's work. Work engagement is not only a positive experience in itself but is also related to job performance (Halbesleben \& Wheeler, 2008; Salanova, Agut, \& Peiró, 2005).

Job demands are the physical, psychological, social, and organizational aspects of a job that require sustained physical, cognitive, and emotional effort and skills (Demerouti, Bakker, Nachreiner, \& Schaufeli, 2001). In line with previous conceptualizations of job demands, we focused on quantitative demands that implied a high workload and time pressure (De Lange et al., 2003). Exposure to high job demands is associated with impaired wellbeing over time (De Lange, Taris, Kompier, Houtman, \& Bongers, 2004; Garst, Frese, \& Molenaar, 2000). When facing high demands, individuals mobilize energy via sympathetic activation and invest extra effort in order to meet the demands (Hockey, 1997). Increased activation and effort investment in turn deplete resources (Zohar, Tzischinski, \& Epstein, 2003), increase the risk of exhaustion (Bakker \& Demerouti, 2007), and overtax the physiological system (McEwen, 1998). High job demands show a substantial bivariate correlation with poor psychological well-being (LePine et al., 2005). Moreover, longitudinal studies have shown that high job demands are related to impaired psychological well-being over time (De Lange et al., 2003; Sonnentag \& Frese, 2003). In our study, we aimed at replicating this relation between high job demands and impaired psychological well-being. We hypothesized:

Hypothesis la: High job demands are positively related to impaired psychological well-being over time.

While there is broad empirical evidence that high job demands are associated with strain symptoms (LePine et al., 2005), the pattern is less clear for work engagement (Bakker \& Demerouti, 2007). We proposed that in the long run, job demands reduce work engagement. Models on effort and energy regulation suggest that high demands require a high degree of effort investment (Hockey, 1997) and drain energy resources (Zohar et al., 2003). Consequently, job demands reduce a person's energy level over time, initiating a "loss spiral" (Hobfoll, 2001, p. 354) that reduces personal resources and makes it difficult to invest effort back into work and to maintain work engagement (Xanthopoulou, Bakker, Demerouti, \& Schaufeli, 2009). Thus, while high demands might be addressed with effort and energy investment in the short term, they will be negatively related to work engagement in the long term. Longitudinal research on the relation between job demands and work engagement is still rare and tends to show a negative relation (Hakanen, Schaufeli, \& Ahola, 2008). We hypothesized: 
Hypothesis $1 b$ : High job demands are negatively related to work engagement over time.

\section{Psychological Detachment From Work During Off-Job Time}

Psychological detachment from work during off-job time refers to the process of temporarily disengaging from work during afterwork hours. With its focus on off-job time, psychological detachment is conceptually distinct from (dis-)engagement processes occurring while an individual is at work (Kahn, 1990; Rothbard, 2001). Compared with integration-segmentation concepts that comprise broad work-life boundary issues (Ashforth, Kreiner, \& Fugate, 2000), psychological detachment is a more narrow concept that refers to not thinking about work during nonwork time. We proposed that psychological detachment from work during off-job time is positively related to psychological well-being over time. Detachment during off-job time implies that job demands present during working time cease to impact on the individual - in both cognitive and affective terms. As a consequence, recovery from these job demands can occur (Meijman \& Mulder, 1998). Psychological detachment from job demands provides the opportunity to calm down and to rebuild affective and energetic resources. Lack of detachment during off-job time, however, implies that one does not experience full relief from job demands as one continues to be occupied with job-related thoughts. Being busy with job-related thoughts during off-job time drains energy, which will impair well-being in the long term.

Cross-sectional and daily survey studies support the view that lack of psychological detachment from work during off-job time is related to impaired psychological well-being (Siltaloppi, Kinnunen, \& Feldt, 2009; Sonnentag, Binnewies, et al., 2008). However, the designs of these earlier studies do not allow for conclusions about the longer term implications of poor psychological detachment. We proposed the following hypothesis:

Hypothesis 2a: Psychological detachment from work during off-job time is negatively related to impaired psychological well-being over time.

We proposed that psychological detachment from work increases work engagement over time. Detaching from work during off-job time implies that the strain process and associated energy drain come to an end and that one engages in activities and thoughts that can provide new resources to be invested in the job when back at work (Binnewies, Sonnentag, \& Mojza, 2010). By detaching from one's job and focusing on other areas of life, one may gain new ideas and perspectives that help to maintain a positive view of one's job (Ruderman, Ohlott, Panzer, \& King, 2002), which should increase work engagement. When one does not detach from work, however, the strain process continues and consumes further resources. As a consequence, subsequent vigor at work will decrease, and an individual will find it more difficult to get fully immersed in his or her job. Previous research on shortterm processes occurring within a few days provides preliminary evidence that psychological detachment from work during off-job time might matter for work engagement (Kühnel, Sonnentag, \& Westman, 2009), but research has been mute concerning longer term consequences of psychological detachment from work. We posited the following hypothesis:
Hypothesis $2 b$ : Psychological detachment from work during off-job time is positively related to work engagement over time.

\section{Interaction Effects Between Job Demands and Psychological Detachment}

We suggest that psychological detachment from work during off-job time moderates the relation between job demands and psychological well-being. High psychological detachment from work should attenuate the relations between job demands and impaired psychological well-being and between job demands and poor work engagement.

When employees face high job demands, their physiological and psychological systems are activated in order to mobilize the energy necessary for meeting job demands (McEwen, 1998). With temporary relief from these demands, for instance at the end of the working day, employees' physiological and psychological systems become deactivated, strain levels that have been elevated temporarily are reduced, and recovery can occur (Craig \& Cooper, 1992; Meijman \& Mulder, 1998). However, when strain levels remain high after job demands have been removed, no recovery can occur, and temporarily elevated strain levels may develop into more serious problems (McEwen, 1998). One important condition for reducing temporarily elevated strain levels is that job demands should be removed not only in the physical but also in the mental sense and that psychological detachment from work should occur. When employees detach from work during off-job time, their strain levels that had been elevated temporarily during work are reduced, and the likelihood that job demands translate into longer term strain symptoms is reduced.

However, when one is not willing or able to psychologically detach from work during off-job time (i.e., when one continues to think about job-related problems and issues or even goes on with accomplishing job-related tasks), strain levels remain elevated. Brosschot, Pieper, and Thayer (2005) have argued that "perseverative cognition" after the exposure to a stressor is the reason that stressors may have negative health implications in the long run. If lack of psychological detachment from work during off-job time persists as a frequent pattern in a high-demand context, it will become increasingly difficult for the organism to reduce high strain levels. Accordingly, temporarily elevated strain levels may develop into more serious long-term strain symptoms such as emotional exhaustion or psychosomatic complaints.

Hypothesis 3a: Psychological detachment moderates the relation between job demands and impaired psychological wellbeing. The relation will be stronger for employees who experience a low degree of psychological detachment than for those who experience a high degree of psychological detachment.

We propose that psychological detachment is also a moderator in the relation between job demands and low work engagement. The job demands-resources model states that job and personal resources are important when job demands are high, particularly for outcomes such as work engagement (Bakker \& Demerouti, 2007; Xanthopoulou, Bakker, Demerouti, \& Schaufeli, 2007). Psychological detachment from work during off-job time helps 
one to build up personal resources, particularly energetic and affective resources (Sonnentag, Mojza, Binnewies, \& Scholl, 2008). We have argued that job demands drain energy, which in turn reduces work engagement. However, when employees who face high job demands detach themselves mentally from work when at home, they can gain new energy, for example, by spending time on reenergizing off-job activities. In such a situation, employees return to work with new energy resources that help them to keep up work engagement in the face of high job demands. When employees in high-demand jobs fail to detach themselves from their work during off-job time, they continue thinking about their demanding job, which drains their energy level even further. As a consequence, they will have less energy that can be invested into the job, and work engagement will decrease further.

Hypothesis 3b: Psychological detachment moderates the negative relation between job demands and work engagement. The negative relation will be stronger for employees who experience a low degree of psychological detachment than for those who experience a high degree of psychological detachment.

\section{Method}

\section{Sample}

We conducted our study in German and Swiss non-profit organizations that offer service for people with special needs. To recruit participants, we contacted residential establishments, sheltered workshops, and educational and day-time facilities and introduced our study as research on "recovery from work-related stress." To encourage participation, we promised a lottery prize, organization-specific feedback, and a booklet on work-stress recovery. For data collection, we offered a paper-based and a webbased version of the survey. In accordance with participants' preferences, we sent 747 paper-based surveys with a pre-stamped return envelope by surface mail and sent 130 e-mail links to the web-based survey to potential participants. At Time 1, the survey was completed by 541 persons (overall response rate: $61.7 \%$ ), with 523 persons providing usable data (82.0\% paper-based surveys). One year later, 356 persons completed the survey $(68.1 \%$ of the Time 1 participants). Time 1 and Time 2 data from 330 persons could be matched. We excluded persons who changed the data collection mode from Time 1 to Time 2 or had missing values on core study variables, resulting in a final sample size of 309. This sample largely overlapped with the sample surveyed in an earlier study (Binnewies, Sonnentag, \& Mojza, 2009).

Most of the participants (67.6\%) were women. The average age was 40.8 years, and the average job tenure was 17.0 years. Our sample included social workers (52.4\%), psychologists and similar professionals $(23.3 \%)$, health care workers $(12.6 \%)$, and administrative and other employees (11.6\%; missing data from $2.9 \%$ ). Overall, $28.9 \%$ of the participants held a supervisory position.

To examine whether sample attrition over time was nonrandom, we compared the persons who participated only at Time 1 with the 309 persons included in the final sample. These two groups did not differ with respect to any study variable.

\section{Measures}

Table 1 shows means, standard deviations, zero-order correlations, and Cronbach's alphas of the study variables. All items were in German.

Job demands. We assessed quantitative job demands (i.e., time pressure) at Time 1 with five items from the Instrument for Stress-Related Job Analysis (Semmer, 1984; Zapf, 1993), a measure that is widely used in German-speaking countries (Garst et al., 2000; Semmer, Zapf, \& Greif, 1996). Participants were instructed to refer to their job conditions (as opposed to their personal working style) when responding to items such as "How often do you face time pressure?" on a 5-point Likert scale $(1=$ very rarely or never; 5 = very often).

Psychological detachment from work. We measured psychological detachment from work during nonwork time at Time 1 with the four-item scale developed by Sonnentag and Fritz (2007). A sample item is "During after-work hours, I forget about work." Respondents were instructed to report their general level of detachment-as opposed to a day- or week-specific level-on a 5-point Likert scale $(1=I$ fully disagree; $5=I$ fully agree $)$.

Emotional exhaustion. Emotional exhaustion was assessed at Time 2 with seven items from the Oldenbourg Burnout Inventory (OLBI; Demerouti et al., 2001). A sample item is "At my work, I feel increasingly drained emotionally." We used the 4-point Likert scale from the OLBI $(1=$ totally disagree; $4=$ totally agree $)$.

Psychosomatic complaints. Psychosomatic complaints were assessed at Time 2 with five items from the measure developed by Mohr (2000). Items referred to symptoms such as heart pain, dizziness, and feeling tense (e.g., "Do you feel dizzy?"). As a response format, we used a 5 -point Likert scale $(1=$ never; $5=$ nearly daily).

Work engagement. We assessed work engagement at Time 2 with the nine-item version of the Utrecht Work Engagement Scale (Schaufeli, Bakker, \& Salanova, 2006). Respondents answered items such as "At my job, I feel strong and vigorous" on a 7-point Likert scale ranging from 0 (never) to 6 (always).

Control variables. Employees who experience low job control, face emotional dissonance, and work under a shift work regime tend to report poorer well-being (De Lange et al., 2003; Demerouti, Geurts, Bakker, \& Euwema, 2004; Zapf, Seifert, Schmutte, Mertini, \& Holz, 2001). Therefore, we included job control, emotional dissonance, and shift work as control variables. As negative affectivity may bias responses in survey studies (Brief, Burke, George, Robinson, \& Webster, 1988), we controlled for negative affectivity. ${ }^{1}$ In addition, we controlled for working hours, leadership position, personal living situation, and mode of data collection (paper-based vs. web-based). To take advantage of our longitudinal data set, we controlled for the Time 1 scores of our outcome variables.

In detail, we assessed job control at Time 1 with five items from the scale developed by Semmer (1984) and Zapf (1993). Items (e.g., "Can you influence the way how you accomplish your

${ }^{1}$ Because controlling for negative affectivity has been criticized (e.g., Spector, Zapf, Chen, \& Frese, 2000), we repeated all our analyses without negative affectivity as a control variable. Significant findings did not change. In addition, psychological detachment at Time 1 was a significant predictor of work engagement at Time 2. 
Table 1

Means, Standard Deviations, Correlations, and Cronbach's Alphas for All Study Variables

\begin{tabular}{|c|c|c|c|c|c|c|c|c|c|c|c|c|c|c|c|c|c|c|c|}
\hline Variable & $M$ & $S D$ & 1 & 2 & 3 & 4 & 5 & 6 & 7 & 8 & 9 & 10 & 11 & 12 & 13 & 14 & 15 & 16 & 17 \\
\hline 1. Data type & 0.17 & 0.38 & - & & & & & & & & & & & & & & & & \\
\hline 2. Leadership position & 0.29 & 0.45 & .03 & - & & & & & & & & & & & & & & & \\
\hline 3. Shift work & 0.31 & 0.46 & -.00 & -.04 & - & & & & & & & & & & & & & & \\
\hline 4. Working hours & 35.7 & 10.2 & .12 & .25 & .03 & - & & & & & & & & & & & & & \\
\hline 5. Living with a partner & 0.76 & 0.43 & .07 & -.05 & -.02 & .01 & - & & & & & & & & & & & & \\
\hline 6. Living with children & 1.55 & 0.50 & -.06 & -.07 & -.15 & -.10 & .20 & - & & & & & & & & & & & \\
\hline 7. Job control (Time 1) & 3.92 & 0.57 & .09 & .15 & -.09 & .01 & -.05 & .03 & .77 & & & & & & & & & & \\
\hline $\begin{array}{l}\text { 8. Emotional dissonance } \\
\text { (Time 1) }\end{array}$ & 2.68 & 0.82 & .05 & .09 & -.00 & .16 & -.02 & -.05 & -.06 & .85 & & & & & & & & & \\
\hline 9. Negative affectivity & & & & & & & & & & & & & & & & & & & \\
\hline (Time 1) & 1.57 & 0.47 & -.11 & .01 & .09 & .10 & -.04 & -.06 & -.16 & .28 & .86 & & & & & & & & \\
\hline $\begin{array}{l}\text { 10. Job demands (Time 1) } \\
\text { 11. Psychological }\end{array}$ & 2.60 & 0.86 & .01 & .29 & -.06 & .12 & .05 & -.03 & -.07 & .22 & .16 & .86 & & & & & & & \\
\hline $\begin{array}{l}\text { detachment (Time 1) } \\
\text { 12. Emotional exhaustion }\end{array}$ & 3.23 & 0.79 & .01 & -.07 & -.12 & -.12 & -.01 & .05 & -.03 & -.05 & -.39 & -.21 & .83 & & & & & & \\
\hline $\begin{array}{l}\text { (Time 1) } \\
\text { 13. Emotional exhaustion }\end{array}$ & 2.24 & 0.53 & -.05 & .05 & -.01 & .11 & -.01 & -.04 & -.21 & .32 & .56 & .36 & -.32 & .85 & & & & & \\
\hline $\begin{array}{l}\text { 13. Emotional } \\
\text { (Time 2) }\end{array}$ & 2.27 & 0.56 & -.06 & .14 & .02 & .21 & -.01 & -.04 & -.10 & .25 & .42 & .34 & -.34 & .68 & .84 & & & & \\
\hline $\begin{array}{l}\text { 15. Psychosomatic } \\
\text { complaints (Time 2) }\end{array}$ & 2.15 & 0.82 & -.05 & .04 & -.01 & .18 & .04 & -.01 & -.13 & .27 & .48 & .27 & -.27 & .48 & .51 & .76 & .75 & & \\
\hline $\begin{array}{l}\text { 16. Work engagement } \\
\text { (Time 1) }\end{array}$ & 4.93 & 1.01 & .05 & .00 & -.04 & .04 & .08 & .01 & .22 & -.20 & -.28 & -.02 & -.12 & -.38 & -.22 & -.19 & -.12 & .94 & \\
\hline $\begin{array}{l}\text { 17. Work engagement } \\
\text { (Time 2) }\end{array}$ & 4.46 & 1.10 & .07 & -.02 & .05 & .01 & .02 & -.00 & .05 & -.15 & -.27 & -.13 & .06 & -.38 & -.47 & -.21 & -.27 & .61 & .93 \\
\hline
\end{tabular}

$$
\text { (Time 2) }
$$

Note. $N=309$. Correlations $\geq 0.11$ are significant with $p>05$; correlations $\geq 0.15$ are significant with $p<.01$. Data type: $0=$ paper-based survey, $1=$ web-based survey; shift work: $0=$ no shift work, 1 = shift work; leadership position: $0=$ no leadership position, $1=$ leadership position; living with partner: $0=$ no, $1=$ yes: living with children: $0=$ no, $1=$ yes. 
tasks?") had to be answered on a 5-point Likert scale ( 1 = very little; 5 = to a high degree). We measured emotional dissonance with five items from the scale developed by Zapf, Vogt, Seifert, Mertini, and Isic (1999). Items (e.g., "How often does it occur in your job that one has to display positive emotions that do not correspond to what is felt in this situation?") were answered on a 5 -point Likert scale $(1=$ very seldom or never; $5=$ very often $)$. We gauged negative affectivity with the 10 negative affect items from the Positive Affect Negative Affect Scale (Watson, Clark, \& Tellegen, 1988). Respondents were asked to report how they felt in general (e.g., "irritable," "nervous"). We assessed well-being at Time 1 as control variables (i.e., emotional exhaustion, psychosomatic complaints, and work engagement) with the same items as used at Time 2.

Construct validity. To examine if the multi-item measures assessed at Time 1 represent distinct constructs, we specified an eight-factor model (job demands, psychological detachment, job control, emotional dissonance, emotional exhaustion, psychosomatic complaints, work engagement, and negative affectivity) with all items loading only on their respective factors. This model showed a good fit, $\chi^{2}(1147)=1964.01$, root-mean-square error of approximation $($ RMSEA $)=0.050$, confirmatory fit index $(\mathrm{CFI})=$ 0.95 , nonnormed fit index (NNFI) $=0.95$, and fit the data better than a one-factor model, $\Delta \chi^{2}(30) \leq 7021.28, p<.001$, and all plausible alternative models. Similarly, with respect to the three outcome variables assessed at Time 2 (emotional exhaustion, psychosomatic complaints, work engagement), we compared a threefactor model with all items loading on their respective factors, $\chi^{2}(186)=521.59$, RMSEA $=0.077$, CFI $=0.96$, NNFI $=0.96$, with a one-factor model, $\Delta \chi^{2}(3)=2138.71, p<.001$, and all possible two-factor models, $\Delta \chi^{2}(2) \leq 274.66, p<.001$. Overall, these confirmatory factor analyses showed that all variables could be differentiated at the construct level.

\section{Results}

\section{Test of Hypotheses}

We tested our hypotheses with three sets of hierarchical regression analyses in which we regressed emotional exhaustion, psychosomatic complaints, and work engagement (assessed at Time 2) on job demands, psychological detachment from work during off-job time, and the interaction between these two variables (both assessed at Time 1). We controlled for data type (paper-based vs. web-based survey), shift work, job control, emotional dissonance, working hours, leadership position, and personal living situation, as well as the Time 1 score of the respective outcome variable. Thus, we predicted well-being and work engagement after controlling for initial levels of well-being and work engagement.

Results for emotional exhaustion as outcome variable are shown in Table 2. Working hours and emotional exhaustion at Time 1 entered as a control variables predicted emotional exhaustion at Time 2. Job demands and psychological detachment entered in the next steps contributed significantly to the prediction of emotional exhaustion. Persons experiencing high job demands and low levels of psychological detachment reported a significant increase in emotional exhaustion. The interaction term between job demands and psychological detachment did not add to the prediction of emotional exhaustion.
Table 3 shows the results for psychosomatic complaints as outcome variable. Negative affectivity and psychosomatic complaints at Time 1 predicted psychosomatic complaints at Time 2. Job demands added significantly to the prediction of psychosomatic complaints, but psychological detachment did not. The interaction term between job demands and psychological detachment entered in the final step was significant. We examined the pattern of this interaction effect with simple slope tests (Aiken \& West, 1991). At high levels of psychological detachment (one $S D$ above the mean), job demands were not related to psychosomatic complaints $(\beta=0.019, t=0.352, n s)$, but at low levels (one $S D$ below the mean), job demands were positively related to psychosomatic complaints $(\beta=0.164, t=3.113, p<.01)$. This interaction effect illustrated in Figure 1 means that job demands predicted an increase in psychosomatic complaints only when persons did not detach from their job during off-job time.

Table 4 displays the results for work engagement as outcome variable. Low negative affectivity and work engagement at Time 1 were significant predictors of work engagement. Job demands additionally contributed to the prediction of work engagement at Time 2. Persons with high demands at Time 1 reported decreased work engagement at Time 2. Psychological detachment did not contribute to the prediction of work engagement. The interaction between job demands and psychological detachment added to the prediction of work engagement. Simple slope tests (Aiken \& West, 1991) showed that at high levels of psychological detachment (one $S D$ above the mean), job demands were not related to work engagement $(\beta=0.030, t=0.302, n s)$. However, at low levels of psychological detachment (one $S D$ below the mean), job demands were related to a decrease in work engagement $(\beta=-0.305, t=$ $-3.083, p<.01 ;$ cf. Figure 2).

Taken together, Hypotheses 1a and $1 \mathrm{~b}$ were supported. Hypothesis $2 \mathrm{a}$ was supported for emotional exhaustion, and Hypothesis $3 \mathrm{a}$ was supported for psychosomatic complaints. In addition, Hypothesis $3 b$ was supported, but Hypothesis $2 b$ was not. ${ }^{2}$

\footnotetext{
${ }^{2}$ In an additional set of analyses, we tested whether residuals in job demands and residuals in psychological detachment (when predicting job demands at Time 2 from job demands at Time 1 and psychological detachment at Time 2 from psychological detachment at Time 1) predicted residuals in our outcome variables (Tables are available from the first author). In these analyses, we included the same control variables as in the other analyses. For control variables that might change over time, we also used the residuals (i.e., we included the residuals of job control, emotional dissonance, and working hours). Analyses showed that residuals in psychological detachment predicted residuals in emotional exhaustion $(\beta=$ $-0.175 ; t=-4.168 ; p<.001)$ and in psychosomatic complaints $(\beta=$ $-0.127 ; t=-3.296 ; p<.01)$. The interaction between residuals in psychological detachment and residuals in job demands predicted residuals in work engagement over time $(\beta=0.128 ; t=-2.785 ; p<.01)$. The interaction term between residuals in psychological detachment and residuals in job demands was not significant for either emotional exhaustion or psychosomatic complaints. Overall, findings from these analyses with residuals of psychological detachment correspond to the findings from analyses in which the Time-1 levels of psychological detachment were used as predictors.
} 
Table 2

Results From Hierarchical Regression Analysis Predicting Emotional Exhaustion (Time 2) From Job Demands and Psychological Detachment (Time 1)

\begin{tabular}{|c|c|c|c|c|c|c|c|c|}
\hline \multirow[b]{2}{*}{ Variable } & \multicolumn{2}{|c|}{ Model 1} & \multicolumn{2}{|c|}{ Model 2} & \multicolumn{2}{|c|}{ Model 3} & \multicolumn{2}{|c|}{ Model 4} \\
\hline & $\beta$ & $t$ & B & $t$ & $\beta$ & $t$ & B & $t$ \\
\hline Data type & -.057 & -1.287 & -.057 & -1.284 & -.059 & 1.349 & -.059 & -1.339 \\
\hline Leadership position & .091 & 1.952 & .060 & 1.251 & .060 & 1.254 & .060 & 1.236 \\
\hline Shift work & .029 & 0.654 & .037 & 0.825 & .025 & 0.553 & .025 & 0.553 \\
\hline Working hours & .120 & $2.586^{*}$ & .120 & $2.591^{*}$ & .114 & $2.472^{*}$ & .113 & $2.464^{*}$ \\
\hline Living with a partner & -.001 & -0.024 & -.011 & -0.237 & -.011 & -0.243 & -.011 & -0.244 \\
\hline Living with children & .020 & 0.450 & .021 & 0.472 & .023 & 0.526 & .023 & 0.521 \\
\hline Negative affectivity & .047 & 0.889 & .057 & 1.070 & .028 & 0.507 & .028 & 0.507 \\
\hline Job control & .034 & 0.761 & .037 & 0.820 & .024 & 0.526 & .024 & 0.525 \\
\hline Emotional dissonance & .024 & 0.511 & .011 & 0.239 & .025 & 0.530 & .024 & 0.518 \\
\hline Emotional exhaustion (Time 1) & .625 & $11.443^{* * * * *}$ & .587 & $10.351^{* * * *}$ & .570 & $10.034^{\operatorname{min*}}$ & .570 & $9.945^{\text {**** }}$ \\
\hline Job demands & & & .115 & $2.351^{\mathrm{k}}$ & .099 & $2.008^{a}$ & .099 & $1.997^{\text {th }}$ \\
\hline Psychological detachment & & & & & -.103 & $-2.127^{s}$ & -.102 & $-2.002^{*}$ \\
\hline Job Demands $\times$ Psychological Detachment & & & & & & & -.002 & -0.038 \\
\hline$R^{2}$ & & 0.481 & & 0.492 & & 0.500 & & 0.500 \\
\hline$F$ & & $25.434^{\text {***:k }}$ & & $24.007^{k \cdot k \cdot k}$ & & $22.667^{\mathrm{sN}}$ & & $20.847^{* * *}$ \\
\hline$d f$ & & 10,274 & & 11,273 & & 12,272 & & 13,271 \\
\hline$\Delta R^{2}$ & & 0.462 & & 0.010 & & 0.008 & & 0.000 \\
\hline$F$ & & $25.434^{\text {tatax }}$ & & $5.526^{*}$ & & $4.523^{m}$ & & 0.001 \\
\hline$d f$ & & 10,274 & & 1,273 & & 1,272 & & 1,271 \\
\hline
\end{tabular}

Note. $\quad N=309$

" $p<.05 . \quad p<.01$.

\section{Additional Analyses}

To further examine our data, we tested for reverse causation. ${ }^{3}$ Neither emotional exhaustion nor psychosomatic complaints nor low work engagement (assessed at Time 1) predicted psychological detachment at Time 2 . There was no evidence for any interaction effect between job demands and psychosomatic complaints at Time 1 or job demands and work engagement at Time 1 on psychological detachment at Time 2. Taken together, these results suggest that neither emotional exhaustion, psychosomatic complaints, nor low work engagement increases job demands or lack of psychological detachment over time as main or as interaction effects. Work engagement at Time 1 predicted an increase in job demands at Time 2 .

\section{Discussion}

Our longitudinal study showed that lack of psychological detachment from work during off-job time predicted an increase in emotional exhaustion 1 year later. Psychological detachment moderated the relation between job demands and increase in psychosomatic complaints and between job demands and decrease in work engagement. Job demands were related to an increase in psychosomatic complaints and to a decrease in work engagement over time when psychological detachment was low. These results extend previous research in which cross-sectional designs (Fritz, Yankelevich, Zarubin, \& Barger, in press; Taris et al., 2008) or within-person perspectives (Sonnentag, Binnewies, et al., 2008) were used.

Our study adds to research on emotional exhaustion as one core burnout symptom. In addition to the evidence that workplace factors contribute to the development of burnout (Lee \& Ashforth,
1996; Maslach et al., 2001), our study demonstrates that factors related to job-stress recovery outside work matter as well (cf., Sonnenschein, Sorbi, van Doornen, Schaufeli, \& Maas, 2007). Our findings suggest that continued preoccupation with work during off-job time adds to an energy depletion process and contributes to burnout.

Our study contributes new insights into moderators in the demand-strain relation (Warr, 2007), where primarily job control (Parker \& Sprigg, 1999), social support (Dormann \& Zapf, 1999), and variables such as self-efficacy and locus of control (Meier, Semmer, Elfering, \& Jacobshagen, 2008; Schaubroeck, Lam, \& Xie, 2000) have been examined previously. Geurts and Sonnentag (2006) argued that recovery processes moderate the relation between job demands and strains. Psychological detachment from work during off-job time might enable such a recovery process Our study provides first longitudinal evidence that psychological detachment actually works as a moderator and suggests that job demands such as time pressure are less harmful when employees mentally disengage from their job during off-job time. Thus, psychological detachment can be seen as a protective factor in the stressor-strain relation.

We found an additive effect of job demands and psychological detachment on emotional exhaustion, whereas interactive effects between job demands and psychological detachment emerged for psychosomatic complaints and work engagement. This pattern of

${ }^{3}$ Tables are available from the first author upon request. Similar to the high stabilities of emotional exhaustion, psychosomatic complaints, and work engagement from Time 1 to Time 2 (see Table 1), job demands $(r=$ .77) and psychological detachment $(r=.70)$ were rather stable over time. 
Table 3

Results From Hierarchical Regression Analysis Predicting Psychosomatic Complaints (Time 2) From Job Demands and Psychological Detachment (Time 1)

\begin{tabular}{|c|c|c|c|c|c|c|c|c|}
\hline \multirow[b]{2}{*}{ Variable } & \multicolumn{2}{|c|}{ Model 1} & \multicolumn{2}{|c|}{ Model 2} & \multicolumn{2}{|c|}{ Model 3} & \multicolumn{2}{|c|}{ Model 4} \\
\hline & B & $t$ & B & $t$ & B & $t$ & B & $t$ \\
\hline Data type & .015 & 0.383 & .014 & 0.367 & .013 & 0.330 & .020 & 0.509 \\
\hline Leadership position & -.002 & -0.048 & -.028 & 0.189 & -.028 & -0.663 & -.039 & -0.922 \\
\hline Shift work & -.034 & -0.878 & -.026 & -0.676 & -.031 & -0.798 & -.025 & -0.632 \\
\hline Working hours & .076 & 1.861 & .075 & 1.853 & .073 & 1.786 & .069 & 1.699 \\
\hline Living with a partner & .015 & 0.373 & .007 & 0.189 & .008 & 0.195 & .005 & 0.116 \\
\hline Living with children & -.026 & -0.653 & -.025 & -0.618 & -.023 & -0.587 & -.028 & -0.715 \\
\hline Negative affectivity & .126 & $2.787^{\text {*** }}$ & .125 & $2.788^{* * *}$ & .111 & $2.370^{4}$ & .110 & $2.358^{*}$ \\
\hline Job control & -.015 & -0.385 & -.010 & -0.264 & -.016 & -0.395 & -.014 & -0.351 \\
\hline Emotional dissonance & .006 & 0.138 & -.008 & -0.186 & -.002 & -0.046 & -.016 & -0.378 \\
\hline Psychosomatic complaints (Time 1) & .689 & $14.817^{* * * * *}$ & .671 & $14.377^{\text {****** }}$ & .667 & $14.216^{\text {,ithos }}$ & .664 & $14.247^{\text {**:**}}$ \\
\hline Job demands & & & .096 & $2.315^{*}$ & .088 & $2.081^{\text {th }}$ & .095 & $2.263^{\mathrm{m}}$ \\
\hline Psychological detachment & & & & & -.045 & -1.057 & -.014 & -0.314 \\
\hline Job Demands $\times$ Psychological Detachment & & & & & & & -.089 & $-2.129^{\prime \prime}$ \\
\hline$R^{2}$ & & .599 & & .606 & & 608 & & .614 \\
\hline$F$ & & $40.855^{\text {*:*** }}$ & & $38.219^{* \cdot k \cdot k}$ & & $35.142^{* * *}$ & & $33.209^{*+4}$ \\
\hline$d f$ & & 10,274 & & 11,273 & & 12,272 & & 13,271 \\
\hline$\Delta R^{2}$ & & .599 & & .008 & & .002 & & .006 \\
\hline$F$ & & $40.855^{\text {takn }}$ & & $5.357^{*}$ & & 1.117 & & $4.533^{\mathrm{n}}$ \\
\hline$d f$ & & 10,274 & & 1,273 & & 1,272 & & 1,271 \\
\hline
\end{tabular}

Note. $\quad N=309$

${ }^{*} p<.05 . \quad$ " $p<.01$

findings suggests that lack of detachment drains energyirrespective of the level of job demands. Depletion of energy may result in emotional exhaustion over time, particularly because lack of detachment from work during off-job time makes compensatory resource replenishment difficult. Lack of psychological detachment, however, does not necessarily increase psychosomatic complaints. Only when job demands are high does the lack of psychological detachment become problematic, as it may prolong the stressors and increase their impact on the psychological systems.

Also with respect to work engagement, we found no bivariate relation, suggesting that psychological detachment per se does not increase work engagement. Here, two distinct mechanisms might be involved that result in a zero net effect of psychological de-

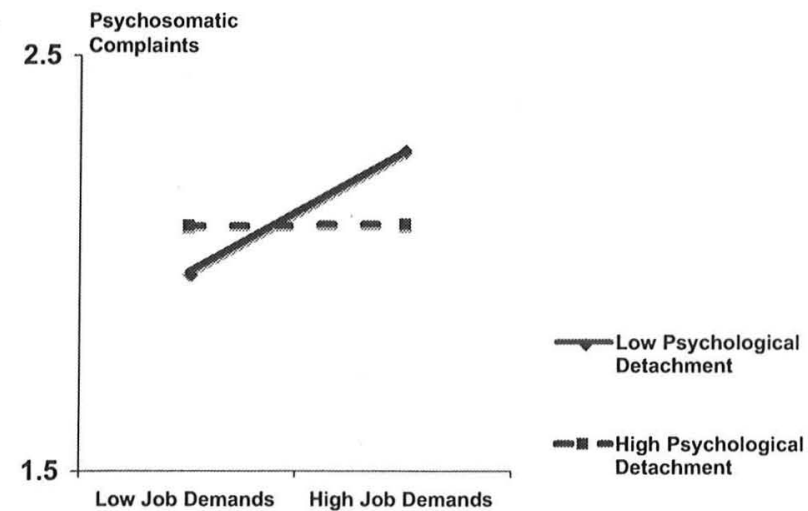

Figure 1. Interaction effect between job demands and psychological detachment on psychosomatic complaints. tachment. The first mechanism refers to the hypothesized negative effect of lack of psychological detachment. When one is thinking and ruminating about job demands during off-job hours, one's work engagement might decrease because energetic resources become depleted. The second mechanism refers to possible positive consequences of reflecting about one's job during off-job time. Particularly when the job situation is characterized by positive features, continued mental occupation with one's job might even increase work engagement because thinking about the positive features might increase the willingness to continue one's work with dedication and absorption.

\section{Limitations}

Our study has some limitations. First, we used self-report measures, which might have increased common method bias. Although multisource data (cf. Ilies, Schwind, \& Wagner, 2009) would have been preferable, we tried to minimize common method bias by measuring predictor and outcome variables at different points in time and by controlling for negative affectivity (Podsakoff, MacKenzie, Lee, \& Podsakoff, 2003). Thus, it is unlikely that our findings are solely attributable to common method bias. Second, the correlational nature of our study does not allow us to draw strong causal conclusions. However, because we used a longitudinal design in which we controlled for the initial level of the outcome variables as well as a range of third variables and because we tested for reverse causation (Shadish, Cook, \& Campbell, 2001), we tentatively conclude that lack of psychological detachment increases emotional exhaustion over time and amplifies the unfavorable impact of job demands on psychosomatic complaints and work engagement. However, well-controlled intervention studies 
Table 4

Results From Hierarchical Regression Analysis Predicting Work Engagement (Time 2) From Job Demands and Psychological Detachment (Time 1)

\begin{tabular}{|c|c|c|c|c|c|c|c|c|}
\hline \multirow[b]{2}{*}{ Variable } & \multicolumn{2}{|c|}{ Model 1} & \multicolumn{2}{|c|}{ Model 2} & \multicolumn{2}{|c|}{ Model 3} & \multicolumn{2}{|c|}{ Model 4} \\
\hline & B & $t$ & B & $t$ & B & $t$ & B & $t$ \\
\hline Data type & .050 & 1.035 & .049 & 1.032 & .051 & 1.079 & .042 & 0.892 \\
\hline Leadership position & .006 & 0.118 & .037 & 0.721 & .038 & 0.729 & .052 & 1.001 \\
\hline Shift work & .011 & 0.230 & .000 & 0.006 & .009 & 0.181 & .000 & 0.001 \\
\hline Working hours & -.015 & -0.295 & -.013 & -0.257 & -.008 & -0.161 & -.003 & -0.059 \\
\hline Living with a partner & -.036 & -0.737 & -.026 & -0.535 & -.026 & -0.545 & -.022 & -0.462 \\
\hline Living with children & -.004 & -0.083 & -.004 & -0.088 & -.006 & -0.119 & .001 & 0.018 \\
\hline Negative affectivity & -.146 & $-2.931^{\text {*** }}$ & -.133 & $-2.668^{*}$ & -.096 & -1.766 & -.092 & -1.705 \\
\hline Job control & -.060 & -1.137 & -.070 & -1.448 & -.064 & -1.311 & -.067 & -1.385 \\
\hline Emotional dissonance & -.012 & -0.143 & .009 & 0.185 & .002 & 0.046 & .021 & 0.414 \\
\hline Work engagement Time 1 & .578 & $11.522^{* * * *}$ & .590 & $11.789^{* * * m}$ & .609 & $11.930^{* * * * a+6}$ & .612 & $12.075^{\text {***** }}$ \\
\hline Job demands & & & -.115 & $-2.271^{\mathrm{h}}$ & -.099 & -1.929 & -.108 & $-2.117^{4}$ \\
\hline Psychological detachment & & & & & .092 & 1.736 & .053 & 0.953 \\
\hline Job Demands $\times$ Psychological Detachment & & & & & & & .114 & $2.227^{\prime \prime}$ \\
\hline$R^{2}$ & & 0.395 & & 0.406 & & 0.413 & & 0.423 \\
\hline$F$ & & $17.885^{\text {жан }}$ & & $16.975^{\ldots+k}$ & & $15.926^{n+x+1}$ & & $15.296^{\mathrm{as}}$ \\
\hline$d f$ & & 10,274 & & 11,273 & & 12,272 & & 13,271 \\
\hline$\Delta R^{2}$ & & 0.395 & & 0.011 & & 0.007 & & 0.011 \\
\hline$F$ & & $17.885^{w * * *}$ & & $5.155^{\text {th }}$ & & 3.013 & & $4.959^{\circ}$ \\
\hline$d f$ & & 10,274 & & 1,273 & & 1,272 & & 1,271 \\
\hline
\end{tabular}

Note. $\quad N=309$

${ }^{*} p<.05 . \quad{ }^{* * *} p<.01$.

(Semmer, 2006) are needed in order to demonstrate the causality that we assumed here. Third, we focused on time pressure as one aspect of high job demands. Future studies should cover a broader range of job demands and explicitly include high emotional and cognitive demands.

\section{Directions for Future Research}

Our study focused on indicators of well-being and work engagement. In the future, researchers may want to expand the scope of the outcome variables and include physiological measures. If one assumes that lack of detachment contributes to prolonged activa-

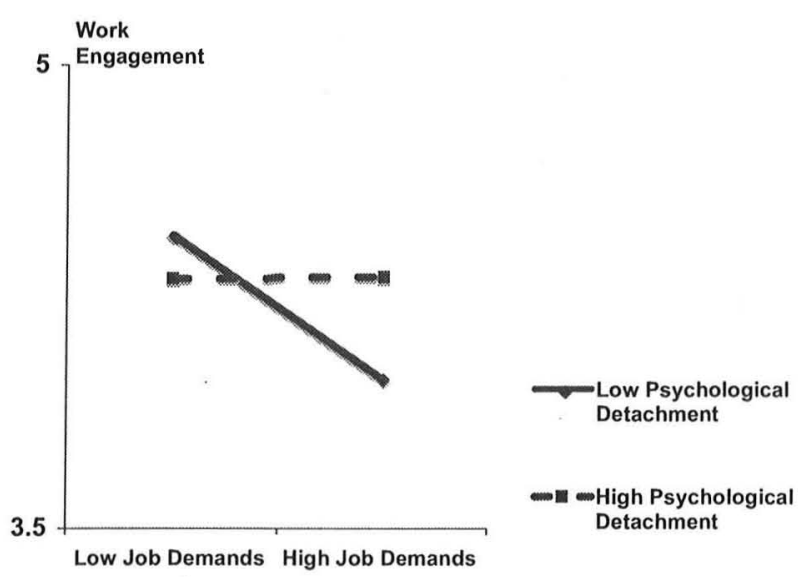

Figure 2. Interaction effect between job demands and psychological detachment on work engagement. tion (Brosschot et al., 2005), endocrinological and cardiovascular indicators are likely to be affected by a lack of psychological detachment from work. Lack of detachment from work might also affect behaviors at home. A person who is constantly busy with work-related thoughts during off-job time might be less attentive and less responsive to others in his or her home environment. As a consequence, conflicts within the family might increase (cf. Story \& Repetti, 2006).

Lack of detachment might not always be detrimental. Fritz and Sonnentag $(2005,2006)$ showed that positive work reflection during weekends and vacations increases the well-being of employees when they return to work. Moreover, research has indicated that social support from the nonwork domain protects health and well-being (Halbesleben, 2006). To gain social support from nonwork sources, employees need to talk about job-related topics. Thus, when fully detaching from work during off-job time, they might miss support that family members or friends could provide. We suggest that possible specific benefits of nondetachment from work be addressed in future studies.

Moreover, it is important to learn more about the factors that enable detachment. For example, age and individual-difference factors might be relevant. In addition, research on role boundaries suggests that employees differ in the degree to which they wish to integrate versus segment their work and nonwork lives (Kossek, Lautsch, \& Eaton, 2006; Rothbard, Philips, \& Dumas, 2005). Possibly, employees preferring segmentation might find it easier to psychologically detach from work during off-job time than do employees preferring integration.

Finally, time-lag issues in longitudinal research remain unresolved. Therefore, in future studies, our findings should be examined to determine whether they can be generalized to different time lags. 


\section{Directions for Practice}

Although we were unable to demonstrate causality in a strict sense and although there might be specific benefits of not detaching from work, overall, our findings suggest that employees should detach from work during off-job time, particularly when job demands are high. One way that employees can detach is to use rituals of separation at the boundary between their job and their off-job life (Ashforth et al., 2000). Employees could use rituals such as winding down at the end of the working day or deliberately using commuting time to disengage from job-related thoughts. Furthermore, engagement in off-job activities that require one's full presence and awareness might increase psychological detachment from work.

\section{References}

Affleck, G., Zautra, A., Tennen, H., \& Armeli, S. (1999). Multilevel daily process designs for consulting and clinical psychology: A preface for the perplexed. Journal of Consulting and Clinical Psychology, 67, 746-754.

Aiken, L. S., \& West, S. G. (1991). Multiple regression: Testing and interpreting interactions. Newbury Park, CA: Sage.

Ashforth, B. E., Kreiner, G. E., \& Fugate, M. (2000). All in a day's work: Boundaries and micro role transitions. Academy of Management Review, $25,472-491$.

Bakker, A. B., \& Demerouti, E. (2007). The job demands-resources model: State of the art. Journal of Managerial Psychology, 22, 309-328.

Binnewies, C., Sonnentag, S., \& Mojza, E. J. (2009). Feeling recovered and thinking about the good sides of one's work: A longitudinal study on the benefits of non-work experiences for job performance. Journal of Occupational Health Psychology, 14, 243-256.

Binnewies, C., Sonnentag, S., \& Mojza, E. J. (2010). Recovery during the weekend and fluctuations in weekly job performance: A four-week longitudinal study examining intra-individual relationships. Journal of Occupational and Organizational Psychology, 83, 419-441.

Brief, A. P., Burke, M. J., George, J. M., Robinson, B. S., \& Webster, J. (1988). Should negative affectivity remain an unmeasured variable in the study of job stress? Journal of Applied Psychology, 73, 193-198.

Brosschot, J. F., Pieper, S., \& Thayer, J. F. (2005). Expanding stress theory: Prolonged activation and perseverative cognition. Psychoneuroendocrinology, 30, 1043-1049.

Craig, A., \& Cooper, R. E. (1992). Symptoms of acute and chronic fatigue. In A. P. Smith \& D. M. Jones (Eds.), Handbook of human performance (Vol. 3, pp. 289-339). London, England: Academic Press.

Darr, W., \& Johns, G. (2008). Work strain, health, and absenteeism: A meta-analysis. Journal of Occupational Health Psychology, 13, 293318.

De Lange, A., Taris, T. W., Kompier, M. A. J., Houtman, I. L. D., \& Bongers, P. M. (2004). The relationships between work characteristics and mental health: Examining normal, reversed and reciprocal relationships in a 4-wave study. Work \& Stress, 18, 149-166.

De Lange, A. H., Taris, T. W., Kompier, M. A. J., Houtman, I. L. D., \& Bongers, P. M. (2003). "The very best of the millenium": Longitudinal research and the demand-control-(support) model. Journal of Occupational Health Psychology, 8, 282-305.

Demerouti, E., Bakker, A. B., Nachreiner, F., \& Schaufeli, W. B. (2001). Job demands-resources model of burnout. Journal of Applied Psychology, 86, 499-512.

Demerouti, E., Geurts, S. A. E., Bakker, A. B., \& Euwema, M. (2004). The impact of shiftwork on work-home conflict, job attitudes, and health. Ergonomics, 47, 987-1002.

Dormann, C., \& Zapf, D. (1999). Social support, social stressors at work, and depressive symptoms: Testing for main and moderating effects with structural equations in a three-wave longitudinal study. Journal of Applied Psychology, 84, 874-884.

Etzion, D., Eden, D., \& Lapidot, Y. (1998). Relief from job stressors and burnout: Reserve service as a respite. Journal of Applied Psychology, 83 , $577-585$.

Fritz, C., \& Sonnentag, S. (2005). Recovery, health, and job performance: Effects of weekend experiences. Journal of Occupational Health Psychology, 10, 187-199.

Fritz, C., \& Sonnentag, S. (2006). Recovery, well-being, and performancerelated outcomes: The role of workload and vacation experiences. Journal of Applied Psychology, 91, 936-945.

Fritz, C., Yankelevich, M., Zarubin, A., \& Barger, P. (in press). Happy, healthy, and productive: The role of detachment from work during nonwork time. Journal of Applied Psychology.

Ganster, D. C., Fox, M. L., \& Dwyer, D. J. (2001). Explaining employees' health care costs: A prospective examination of stressful job demands, personal control, and physiological reactivity. Journal of Applied Psychology, 86, 954-964.

Garst, H., Frese, M., \& Molenaar, P. C. M. (2000). The temporal factor of change in stressor-strain relationships: A growth curve model on a longitudinal study in East Germany. Journal of Applied Psychology, 85, $417-438$.

Geurts, S. A. E., \& Sonnentag, S. (2006). Recovery as an explanatory mechanism in the relation between acute stress reactions and chronic health impairment. Scandinavian Journal of Work, Environment and Health, 32, 482-492.

Hakanen, J. J., Schaufeli, W. B., \& Ahola, K. (2008). A three-year cross-lagged panel study on the job demands-resources model: Do home demands and resources play a role? Work \& Stress, 22, 224-241.

Halbesleben, J. R. B. (2006). Sources of social support and burnout: A meta-analytic test of the conservation of resources model. Journal of Applied Psychology, 91, 1134-1145.

Halbesleben, J. R. B., \& Wheeler, A. R. (2008). The relative role of engagement and embeddedness in predicting job performance and turnover intention. Work \& Stress, 22, 242-256.

Hobfoll, S. E. (2001). The influence of culture, community, and the nested-self in the stress process: Advancing conservation of resources theory. Applied Psychology: An International Review, 50, 337-421.

Hockey, G. R. J. (1997). Compensatory control in the regulation of human performance under stress and high workload: A cognitive-energetical framework. Biological Psychology, 45, 73-93.

Ilies, R., Schwind, K. M., \& Wagner, D. T. (2009). The spillover of daily job satisfaction onto employees' family lives: The facilitating role of work-family integration. Academy of Management Journal, 52, 87-102.

Ilies, R., Schwind, K. M., Wagner, D. T., Johnson, M. D., DeRue, D. S., \& Ilgen, D. R. (2007). When can employees have a family life? The effects of daily workload and affect on work-family conflict and social behavior at work. Journal of Applied Psychology, 92, 1368-1379.

Jex, S. M., \& Yankelevich, M. (2008). Work stress. In J. Barling \& C. L. Cooper (Eds.), The SAGE handbook of organizational behavior: Vol. 1 . Micro approaches (pp. 498-518). London, England: Sage.

Kühnel, J., Sonnentag, S., \& Westman, M. (2009). Does work engagemen increase after a short respite? The role of job involvement as a doubleedged sword. Journal of Occupational and Organizational Psychology, 82, 575-594.

Kahn, W. A. (1990). Psychological conditions of personal engagement and disengagement at work. Academy of Management Journal, 33, 692-724.

Kossek, E. E., Lautsch, B. A., \& Eaton, S. C. (2006). Telecommuting, control, and boundary management: Correlates of policy use and practice, job control, and work-family effectiveness. Journal of Vocational Behavior, 68, 347-367.

Kreiner, G., Hollensbe, E., \& Sheep, M. L. (2009). Balancing borders and bridges: Negotiating the work-home interface via boundary work tactics. Academy of Management Journal, 52, 704-730. 
Lee, R. T., \& Ashforth, B. E. (1996). A meta-analytic examination of the correlates of the three dimensions of job burnout. Journal of Applied Psychology, 81, 123-133.

LePine, J. A., Podsakoff, N. P., \& LePine, M. A. (2005). A meta-analytic test of the challenge stressor-hindrance stressor framework: An explanation for inconsistent relationships among stressors and performance. Academy of Management Journal, 48, 764-775.

Linden, W., Earle, T. L., Gerin, W., \& Christenfeld, N. (1997). Physiological stress reactivity and recovery: Conceptual siblings separated at birth? Journal of Psychosomatic Research, 42, 117-135.

Maslach, C., Schaufeli, W. B., \& Leiter, M. P. (2001). Job burnout. Annual Review of Psychology, 52, 397-422.

McEwen, B. S. (1998). Stress, adaptation, and disease: Allostasis and allostatic load. Annals of the New York Academy of Sciences, 840, 33-44.

Meier, L. L., Semmer, N. K., Elfering, A., \& Jacobshagen, N. (2008). The double meaning of control: Three-way interactions between internal resources, job control, and stressors at work. Journal of Occupational Health Psychology, 13, 244-258.

Meijman, T. F., \& Mulder, G. (1998). Psychological aspects of workload. In P. J. D. Drenth \& H. Thierry (Eds.), Handbook of work and organizational psychology: Vol. 2. Work psychology (pp. 5-33). Hove, England: Psychology Press.

Mohr, G. B. (2000). The changing significance of different stressors after the announcement of bankruptcy: A longitudinal investigation with special emphasis on job insecurity. Journal of Organizational Behavior, 21, 337-359.

Moreno-Jiménez, B., Mayo, M., Sanz-Vergel, A. I., Geurts, S. A. E., Rodrígez-Munoz, A., \& Garrosa, E. (2009). Effects of work-family conflict on employee's well-being: The moderating role of recovery experiences. Journal of Occupational Health Psychology, 14, 427-440.

Moreno-Jiménez, B., Rodrígez-Munro, A., Pastor, J.-C., Sanz-Vergel, A. I., \& Garrosa, E. (2009). The moderating effect of psychological detachment and thoughts of revenge in workplace bullying. Personality and Individual Differences, 46, 359-364.

Parker, S. K., \& Sprigg, C. A. (1999). Minimizing strain and maximizing learning: The role of job demands, job control, and proactive personality. Journal of Applied Psychology, 84, 925-939.

Podsakoff, P. M., MacKenzie, S. B., Lee, J.-Y., \& Podsakoff, N. P. (2003). Common method biases in behavioral research: A critical review of the literature and recommended remedies. Journal of Applied Psychology, 88, 879-903.

Rothbard, N. P. (2001). Enriching or depleting? The dynamics of engagement in work and family roles. Administrative Science Quarterly, 46, 655-684.

Rothbard, N. P., Philips, K. W., \& Dumas, T. L. (2005). Managing multiple roles: Work-family policies and individuals' desires for segmentation. Organization Science, 16, 243-258.

Ruderman, M. N., Ohlott, P. J., Panzer, K., \& King, S. N. (2002). Benefit of multiple roles for managerial women. Academy of Management Journal, 45, 369-386.

Salanova, M., Agut, S., \& Peiró, J. M. (2005). Linking organizational resources and work engagement to employee performance and customer loyalty: The mediation of service climate. Journal of Applied Psychology, 90, 1217-1227.

Schaubroeck, J., Lam, S., \& Xie, J. L. (2000). Collective efficacy versus self-efficacy in coping responses to stressors and control: A cross cultural study. Journal of Applied Psychology, 85, 512-525.

Schaufeli, W. B., \& Bakker, A. B. (2004). Job demands, job resources, and their relationship with burnout and engagement: A multi-sample study. Journal of Organizational Behavior, 25, 293-315.

Schaufeli, W. B., Bakker, A. B., \& Salanova, M. (2006). The measurement of work engagement with a short questionnaire. A cross-national study. Educational and Psychological Measurement, 66, 701-716.
Schaufeli, W. B., Taris, T. W., \& van Rhenen, W. (2008). Workaholism, burnout, and work engagement: Three of a kind or three different kinds of employee well-being? Applied Psychology: An International Review, 57, 173-203.

Semmer, N. (1984). Streßbezogene Tätigkeitsanalyse [Stress-oriented task analysis]. Weinheim, Germany: Beltz.

Semmer, N., Zapf, D., \& Greif, S. (1996). "Shared job strain": A new approach for assessing the validity of job stress measurements. Journal of Occupational and Organizational Psychology, 69, 293-310.

Semmer, N. K. (2006). Job stress interventions and the organization of work. Scandinavian Journal of Work Environment and Health, 32, 515-527.

Shadish, W. R., Cook, T. D., \& Campbell, D. T. (2001). Experimental and quasi-experimental designs for generalized causal inference. Boston, MA: Houghton Mifflin.

Siltaloppi, M., Kinnunen, U., \& Feldt, T. (2009). Recovery experiences as moderators between psychological work characteristics and occupational well-being. Work \& Stress, 23, 330-348.

Sonnenschein, M., Sorbi, M. J., van Doornen, L. J. P., Schaufeli, W. B., \& Maas, C. J. M. (2007). Electronic diary evidence on energy erosion in clinical burnout. Journal of Occupational Health Psychology, 12, 402413.

Sonnentag, S., \& Bayer, U.-V. (2005). Switching off mentally: Predictors and consequences of psychological detachment from work during offjob time. Journal of Occupational Health Psychology, 10, 393-414.

Sonnentag, S., Binnewies, C., \& Mojza, E. J. (2008). "Did you have a nice evening?" A day-level study on recovery experiences, sleep, and affect. Journal of Applied Psychology, 93, 674-684.

Sonnentag, S., \& Frese, M. (2003). Stress in organizations. In W. C. Borman, D. R. Ilgen, \& R. J. Klimoski (Eds.), Comprehensive handbook of psychology: Vol. 12. Industrial and organizational psychology. (pp. 453-491). Hoboken, NJ: Wiley.

Sonnentag, S., \& Fritz, C. (2007). The Recovery Experience Questionnaire: Development and validation of a measure assessing recuperation and unwinding from work. Journal of Occupational Health Psychology, 12, 204-221.

Sonnentag, S., Mojza, E. J., Binnewies, C., \& Scholl, A. (2008). Being engaged at work and detached at home: A week-level study on work engagement, psychological detachment, and affect. Work \& Stress, 22, 259-276.

Spector, P. E., Zapf, D., Chen, P. Y., \& Frese, M. (2000). Why negative affectivity should not be controlled in organizational stress research: Don't throw out the baby with the bath water. Journal of Organizational Behavior, 21, 79-95.

Story, L. B., \& Repetti, R. (2006). Daily occupational stressors and marital behavior. Journal of Family Psychology, 20, 690-700.

Taris, T. W., Geurts, S. A. E., Schaufeli, W. B., Blonk, R. W. B., \& Lagerveld, S. E. (2008). All day and all of the night: The relative contribution of two dimensions of workaholism to well-being in selfemployed workers. Work \& Stress, 22, 153-165.

Taris, T. W., Le Blanc, P. M., Schaufeli, W. B., \& Scheurs, P. J. G. (2005) Are there causal relationships between the dimensions of the Maslach Burnout Inventory? A review and two longitudinal tests. Work \& Stress, 19, 238-255.

Trougakos, J. P., Beal, D. J., Green, S. G., \& Weiss, H. M. (2008). Making the break count: An episodic examination of recovery activities, emotional experiences, and positive affective displays. Academy of Management Journal, 51, 131-146.

Warr, P. (2007). Work, happiness, and unhappiness. Mahwah, NJ: Erlbaum.

Watson, D., Clark, L. A., \& Tellegen, A. (1988). Development and validation of brief measures of positive and negative affect: The PANAS scales. Journal of Personality and Social Psychology, 54, 1063-1070.

Westman, M., \& Eden, D. (1997). Effects of a respite from work on 
burnout: Vacation relief and fade-out. Journal of Applied Psychology, $82,516-527$

Xanthopoulou, D., Bakker, A. B., Demerouti, E., \& Schaufeli, W. B (2007). The role of personal resources in the job demands-resources model. International Journal of Stress Management, 14, 121-141.

Xanthopoulou, D , Bakker, A. B., Demerouti, E., \& Schaufeli, W. B. (2009). Reciprocal relationships between job resources, personal resources, and work engagement. Journal of Vocational Behavior, 74, 235-244.

Zapf, D. (1993). Stress-oriented analysis of computerized office work European Work and Organizational Psychologist, 3, 85-100.

Zapf, D., Seifert, C., Schmutte, B., Mertini, H., \& Holz, M. (2001). Emotion work and job stressors and their effects on burnout. Psychology and Health, 16, 527-545.
Zapf, D., Vogt, C., Seifert, C., Mertini, H., \& Isic, A. (1999). Emotion work as a source of stress: The concept and the development of an instrument. European Journal of Work and Organizational Psychology, 8, 371-400.

Zohar, D., Tzischinski, O., \& Epstein, R. (2003). Effects of energy availability on immediate and delayed emotional reactions to work events. Journal of Applied Psychology, 88, 1082-1093. 